\title{
Migration of Native American Image by Chinese Yi Poet Akuwuwu
}

\author{
LU Jie \\ The College of Foreign Languages, Chengdu University of Information Technology, China
}

Received May 11, 2020; Revised June 29, 2020; Accepted July 20, 2020

\begin{abstract}
Cite This Paper in the following Citation Styles
(a): [1] LU Jie, "Migration of Native American Image by Chinese Yi Poet Akuwuwu," Linguistics and Literature Studies, Vol. 8, No. 5, pp. 256 - 263, 2020. DOI: 10.13189/lls.2020.080504.
\end{abstract}

(b): LU Jie (2020). Migration of Native American Image by Chinese Yi Poet Akuwuwu. Linguistics and Literature Studies, 8(5), 256 - 263. DOI: 10.13189/lls.2020.080504.

Copyright $\mathrm{C} 2020$ by authors, all rights reserved. Authors agree that this article remains permanently open access under the terms of the Creative Commons Attribution License 4.0 International License

\begin{abstract}
Chinese Yi poet Aku Wuwu's Coyote Traces created in his sojourn in America includes a large number of poems related to Native American mythologies, history and beliefs. In his migration of the Native American image from America to China, Aku devotes to keep the rich connotation and authenticity of the Native American image through his broad visual field and horizontal perspective. Although in most cases, cultural filtration is almost inevitable in the process of cultural migration and the original image is bound to be changed or even distorted, Aku's successful migration of the Native American image proves that an image creator's visual field and perspective can largely decide the result of cultural migration. This thesis analyzes the image of Native Americans shaped by Aku from a comparative literature perspective in order to appeal for readers' attention that cross-cultural writing should narrow the gap between images in literature and in reality, because it should commit to take the responsibility to build a community with a shared future for mankind through the exchange of civilizations which should be constructed on the base of real understanding instead of fantasies.
\end{abstract}

Keywords Aku Wuwu, Coyote Traces, Native American Image Migration, Visual Field, Horizontal Perspective

\section{Introduction}

In 2015, after his sojourn in the United States, Aku
Wuwu $₫$, together with Wen Peihong and Mark Bender, the translators, cooperated to edit and translate a poem collection entitled Coyote Traces: Aku Wuwu's Poetic Sojourn in America. This collection includes 80 poems created in Aku's three visits to America in 2005, 2008 and 2009 respectively. Among these 80 poems, 51 of them are related to the Native American mythologies, history and beliefs. With the publication of the collection in China, due to Aku's great influence among the literary circle of the Chinese Yi people, the Native American image migrated by him bears Yi people or even most Chinese people's "social collective imagination" of the Native American civilization. In other words, Native American image is poetically migrated from America to China by Aku. To avoid cultural filtration and keep the rich connotation and authenticity of Native American image in his poetical migration, Aku is consciously selective in his observation and creation. His success in the migration of the Native American image lies in his broad visual field and horizontal perspective.

\section{Broad Visual Field Guarantees the Rich Connotation of the Native American Image}

Yves Chevrel, the chief professor of Comparative Literature in the Paris Sorbonne University holds "Travel has been the best way to meet foreigners since ancient times" (Chevrel 1989, 35) Judging from the 51 poems related to the Native American civilization in Coyote Traces, Aku has observed the remains and status quo of the 
Native American civilization in almost half of the United States and has reconsidered the destiny of the Native American civilization from the perspective of literary anthropology. His observation of the Native American civilization during his stay in the United States is very broad in terms of space. With the Mississippi River as the watershed, the United States shows great cultural differences between the east and west. In order to gain a more comprehensive and richer understanding of the Native American civilization, Aku's American sojourn began with his visit to Ohio and then headed eastward to Massachusetts, Philadelphia, New York, Vermont, and finally reached westward to Minnesota, Colorado, Oregon and Washington State.

Contemporary Native American scholar Ward Churchill once revealed that "Region by region, people by people, indigenous cultures were overwhelmed and consigned to the reservation status marking the physical characteristics of U.S. internal colonialism. Throughout this era an overarching theme in American writing, from the embryonic work of Charles Brockden Brown and Washington Irving to the late-century tracts of Charles Leland and Alfred Riggs, was the Indian. Or, rather, a certain image of the Indian which complemented the need of the nation's Euroamerican population to supplant the original inhabitants of the land." (Churchill 1998, 12-13) His words properly reveal the essence of the symbolization, flattening and racial profiling of the Native American image in American literary tradition. However, Aku, as a Chinese Yi scholar and poet, is not satisfied with the flat and simplex portrayal of the Native American image in American literature. He said in an interview that the reason for his natural affinity to Native American people lies in his own ethnic minority identity, his profession as a poet, the inborn sympathy toward the weak, his knowledge and academic view, and fraternity of mankind. (Aku 2015, 322) It is precise because of such a strong cultural consciousness that Aku hopes to transfer the Native American image with rich connotations for the Chinese people and even the people of the world. In order to achieve a comprehensive understanding of the object he investigated, he set off from the East Coast, traveled along the route of the Western Expansion, and finally arrived at the West Coast, making surveys on the Native American civilization throughout the United States.

\subsection{Eastern Region: Remembrance of the Splendid Ancient Native American Civilization}

After visiting the Native American stone tools displayed in the State Museum in Ohio in the eastern United States, Aku sincerely praised the wisdom of the ancestors of the Native Americans like this: "With North American stone/ the indomitable Indian ancestors/ created human civilizations" (Aku 2015, 26). According to Dr. Charles Ettner, a Native American scholar in the Department of
Anthropology at Stanford University, archaeological evidence clearly shows that the Native Americans have lived in North America for at least 14,000 years. Other evidences suggest that they may have lived in North America for 30,000 years. (Lan Daju 1996, 78) The stone tools in the museum are material evidences to prove their identities as "American Natives" and to prove to the world that they are not "barbarians". Actually, they had already possessed high intelligence and established considerable civilization before the establishment of colonial settlements in the American continent.

Similarly, in the "Indian Four Sisters", Aku wrote: "Many thousands of years ago/ On the North American land/ myriads of living species flourished./ From among them/ Native ancestors/ inspired by divine spirits/ chose four plants — / corn, pumpkin, sunflower and tobacco leaf." The poet praised the material civilization cultivated by the Native American people with utmost respect, because in his point of view, "Hunting with sharp stone tools,/ they discovered that pumpkin and corn/ could not only sustain life,/ but be raised for their descendants./ Sunflowers can be used to express love;/ Tobacco leaf is their way of conversing with the spirits. "Therefore, Aku warned that "You must take care when walking on North American land,/ Take care not to trample the spirits of the Native ancestors./ Do not forget it was those ancient Indians/ who planted the lovely, magical/ "Four sisters." (Aku 2015, 28) In Aku's point of view, "four sisters" are not just material things but also spiritual treasures the Native American people left for all human beings.

Judging from the two poems written in Ohio when Aku visited the United States for the first time, he had a strong desire to pursue the mysterious and magnificent Native American civilization. Since his $\mathrm{Yi}$ ancestors once also created brilliant civilizations as the ancient Native American did, but both Yi and the Native American people have been experiencing something frustrating and depressing. Similar experiences foster his natural affinity for the Native American civilization. Under the guidance of this "kindred spirit in culture", the poet's imagination of the ancient Native American tribes in the Eastern America formed a spiritual "Utopia" in his literary world, which embodied the poet's remembrance of the beautiful, natural, tranquil and quaint lifestyle once possessed by ethnic minorities in the world.

\subsection{Westbound Travel: Reflections on the Native American's Historical Trauma and Present Dilemmas}

After leaving the east and headed for the west, obvious changes in the mood can be easily detected in Aku's poems. Especially after arriving in Minnesota, he felt an agony in the vertex of "cultural identity" and "cultural criticism". On the one hand, he was proud of the cultural heritage left by the Native Americans. On the other hand, he was 
distressed by the suffering of the Native Americans in the "Western expansion". In Minnesota, he discovered the Native American people's unique wisdom from their "four-color knot" and "medicine bag".

In "Four Colors", because red, yellow, black, and white are just the colors of the human races, the knot woven by the Native Americans with these four-color grasses is regarded as a symbol of their superior "abstract ability", $\mathrm{Aku}$ consequently praised: "As long as human life is capable of abstraction,/ the cognition of who are one's enemies/ gives people much wisdom." (Aku 2015, 64) In "Medicine Bag", Aku was told to put the leaves or stones that were picked up in the happy place into a little bag made of deer hide to relieve the sorrow, so he picked up a cobble on the river bank and put it in the bag, and then as if his whole life "would be filled with all the freedom and happiness of the Mississippi River". (Aku 2015, 84) Obviously, Aku obtained the secret of preserving happiness from ancient Native American wisdom. In the poet's view, the sorrow-forgetting medicine bag is undoubtedly a manifestation of the Native American people's fortitude and optimism. Judging from the above verses, Aku admired ancient Native American civilization and showed a kind of "cultural recognition". However, as a transnational cultural communicator for different ethnic groups, rather than an ordinary tourist, his cultural consciousness pushes him to think more and deeper. Therefore, his other works created in Minnesota reflect a strong sense of historical anxiety and critical responsibility. For example, when enjoying the night view of Minnesota, $\mathrm{Aku}$ associated the beautiful scenery with the Native American people's blood and tears in the "Western expansion". In "An Aerial View of Minnesota", he wrote: "Under the glimmering moonlight,/ the lives of the Natives, / have encountered alluring traps." (Aku 2015, 55) Again in "Moonlight Over Minnesota", he felt "In the eyes of the Native descendants,/ the night moon in Minnesota,/ is just like a sleeping baby, always/ in tears." (Aku 2015, 57) As a Chinese poet, the image of bright moon is always associated with consummation, reunification and happiness, while Aku was well aware of the fact that the "Western expansion" is a piece of high-spirited song for the dominant white Anglo-Saxon Protestants in American culture, but it is an unforgettable traumatic memory for the Native Americans. "The places that the US government chooses to give to Native Americans to dwell in and live in are usually such places: 1 . places that whites are not interested in; 2. places far away from the whites' living areas; 3 . places easy to be controlled by military forces. The government usually knows that these places are places where natural resources are relatively scarce." (Lan Daju $1996,79)$ Nowadays, if only the above explanatory text is used to record the influence of the American "Western expansion" on the Native Americans, the agony is often only superficial and temporary. However, in his poetic language, Aku used the image of a baby who fell asleep with tears to vividly show the helplessness of the Native Americans who were forced to leave their homeland by the powerful and ruthless colonists. Even after being translated into English and undergoing the "filtration" of language and culture, his poetic emotions can still stimulate the deep resonance of many readers.

On the one hand, what Aku saw in his journey was the Native American people's ancient and magnificent wisdom, on the one hand, what he thought of in his journey was the Native American people's historical situation of being oppressed and insulted. This strong contrast prompted him to probe into the mystery and tried to find the answer on the way to the West. In "Secret Funeral", he wrote down his confusion: "The Native American created a history/ of civilizations lasting thousands of years./ Yet, no one has spent any time to ask/ what should be preserved / and what can be preserved/ in the process of being gulped and devoured." Although Aku did not explicitly express his views on which should be abandoned in the poem, he wrote with deep meaning and regretted at the end of the poem: "On a snowy afternoon in spring,/ a full-blooded American Indian/ in the town of St. Poul, Minnesota,/ firmly refused to answer,/ my questions about their funeral rituals today." (Aku 2015, 83) The readers can feel the poet's critical attitude towards such a "secret funeral" from the lines. As a Yi scholar and poet, Aku has always been at the forefront of promoting $\mathrm{Yi}$ culture. He not only uses his native language, Nuosu, but also his native Chinese mandarin to write poetry. In addition, He endeavors to spread the Yi culture to international community in English. He strives to promote the Sino-US cultural exchanges and has established a long-term partnership for Southwest Minzu University and Ohio State University. In 2018, he and Professor Mark Bender finished their 10 years of translation of Yi's national epic Eleteyi(《勒俄特依》) into English and published The Nuosu Book of Origins in the United States. Whether it is for language or culture, Aku always believes that "fruits from grafted tree are sweet, children of mixed blood are smart". (Aku 2015, 198) Judging from his poem creation and cultural activities, he does not agree with cultural conservatism. The old Native American's rejection of his inquiry into the funeral seems to be a "simple national sentiment" that superficially could gain wide sympathy, but in essence was a fundamentalist conservative act. In today's cultural context of "global localization" (Glocalization), it is important to preserve a nation's cultural uniqueness, but progress and improvement through integration and communication between different nations are also inevitable. Aku has being always advocated the idea of "equality in diversity" to realize multiple symbiosis and isomorphic grandness, and his proposition coincides with the viewpoint put forward by famous Chinese scholar Wu Xiaoming in his "Differentiation and Recognition in Cultural Interflow". $\mathrm{Wu}$ holds it is impossible for one culture to avoid encountering other cultures. This is not just the case in 
today's so-called "globalized" era. Any particular culture must come into being in the activity of "regarding Zhou as insider and national minorities $\mathrm{Yi}$ and $\mathrm{Di}$ as outsiders (内诸夏而外夷狄)" or “including Self and excluding the Others (内自己而外他者)”. In a very fundamental sense, "differentiating the insider from outsider" is the inevitable activity for anyone who seeks self-identity or who always needs to identify himself (individual, community, nation, country, specific culture) in order to be what he is. But this inevitable activity of "differentiating the insider from outsider" is accompanied by the question of how to get along with each other and how to communicate with other cultures.(Wu Xiongming 2012, 49)The Indian men's rejection of the poet's inquiry about their funeral is obviously an act of pursuing their own self-identity through "cultural differentiation", but their disregard for the value of cultural exchange evidently goes against their needs to develop their own culture.

Keeping on traveling westward, the poet came to Oregon. A monograph Indian Myths and Legends in Oregon, USA. edited by Gerald Ramsay contains more than 100 oral folklore stories of American aborigines which were "rescued" by American anthropologists. These stories "really reflect the reality of the Oregon Indians in many aspects, showing their rich imagination and ingenuity, indicating that they are kind, courageous, great people".(Ramsay 1983, 8) This book was translated into Chinese by Shi Kun and Li Wusheng in 1983 and became important document to study the Native American folk literature in China. The translators put it in the foreword that "the deification of Coyote is a portrayal of the self-image and life reality of the Indians of the past generations.......Although different nationalities have their own cultural characteristics, the legend about Coyote is be comparable to Chinese Tibetan epic The King Gesar (格萨尔王)and Chinese Yao ethnic myth Miluotuo(密洛陀) in terms of bravery, creation of the world and blessing of the people."(Ramsay 1983, 6) Although the translators only compares Coyote with the legendary figures of Tibetan and Yao nationalities in China in the foreword, there is no doubt that Aku, as a Yi poet, must have found its cultural counterparts in his own nation_—Bimo"(毕摩). Therefore, the dual identity of both a literary anthropologist and a poet makes the deified image of Coyote engraved in Aku's heart. In Aku's perception, Oregon is Coyote's homeland, so he made his pilgrimage to Oregon, exploring the origin of Native American civilization and seeking the Coyote's traces. On May 12, 2005, Aku created "Future River" here. When seeing the reservations along "Willamette River" in Salem City, so he wrote: "Between the dense woods, / live some Indians,/ confident and full of joy." After communicating with these earnest and dear natives, Aku felt "as if returning to my own village". He believed that it is God Coyote who commanded the Willamette River to breed Indian people's optimistic disposition, so after experiencing so many hardships, the Indians in the reservation could still demonstrated "generous spirit re-bloom in the depths of their life." (Aku 2015, 97)

Because of Coyote's great influence on the Native American culture, Aku poetically reproduces his mythological and legendary image in the following works such as "Salmon", "Coyote", "Poisonous Snake" and "Stealing Fire". However, on November 10th, 2009, when the poet visited Oregon again four years later, he found that under the crush of industrial civilization and wheel of time, both the Native American and Coyote's traces disappeared. He regretfully wrote "Where have you hidden yourselves? I've come from afar/ to visit our common divine spirit. In the street of Eugene, / I found not a trace of you. On the campus of Oregon University/ I didn't see your shadow." (Aku 2015, 265) In order to restore the Native American image with rich connotations, Aku has taken consideration of both the expansiveness of space and long-span time dimension.

In general, Aku, as a transnational ethnic cultural communicator, a literary anthropologist and a poet, has explored the positive factor of optimism in the Native American culture and criticized its over-rigid and conservative ideology. On the one hand, he sorrows over the sufferings in its history and is worried about its predicament in the present. The poems he created on the way to the west best demonstrated his writing purpose: let the English-speaking readers see "the responsibility and conscience of a Chinese ethnic minority poet". (Aku 2015,341)

\subsection{Thoughts on the West Coast: Worries about the Future for the Native Americans}

Seattle is the westernmost city in the United States that Aku has arrived in. He talked about his imagination about the city before his arrival__ "a heritage left to descendants/ by alms-giving American Indian ancestors." (Aku 2015, 231)

The city of Seattle is named after a chief. In December 1854, he delivered a speech to the governors of Washington State, white immigrants, and the Native Americans as well. His speech is regarded as the most touching words on the environmental protection for his deep love of nature which shocked the white colonists. David Swinson Maynard, one of the founders of the settlement, suggested that this land should be named after the chief "Seattle".

Chief Seattle once stately said in his speech: "This shining water that moves in the streams and rivers is not just water but the blood of our ancestors......each ghostly reflection in the clear water of the lakes tells of events and memories in the life of my people. The water's murmur is the voice of my father's father. The rivers are our brothers, they quench our thirst. The rivers carry our canoes, and feed our children. If we sell you our land, you must 
remember, and teach your children, that the rivers are our brothers and yours, and you must henceforth give the rivers the kindness you would give any brother."(Seattle 2019) Moved and inspired by the Native Americans' deep affection for nature and advanced ecological wisdom, Aku wrote in "Seattle Bathed in Autumn Rain": "Last night, some fishes went ashore/ and some people went to the sea./ I indescribably feared that / the genuine Seattle will unexpectedly awake." "Some fishes went ashore" and "some people went to the sea" are the poetic elucidation of the flesh-and-blood relationship between human beings and the earth, rivers, air, animals and plants pointed out by the chief Seattle. It can be seen that the Indian concepts of "everything is alive" and "worship of ancestors" have deeply influenced Aku. Therefore, he found "the genuine Seattle" in his dream was the sacred land that the Indians once lived in. His worry about suddenly waking up from his dream reflected his anxiety about the deterioration of the future ecological environment and the difficult survival and development of the Native American people.

From the perspective of literary geography, Aku's investigation of the Native American civilization is vast in space. The spatial dimension of the United States from east to west ensures his full and comprehensive understanding of the Native American civilization. The Native American image presented in his poetry is different from not only the dirty and barbaric image of an inferior race described in Nathaniel Hawthorne's The Scarlet Letter or Mark Twain's Roughing It but also "the noble savages" in James Fenimore Cooper's The Leatherstocking Tales and Henry Wadsworth Longfellow's The Song of Hiawatha. The Native American migrated by Aku once created splendid civilization and possessed excellent wisdom, but suffered from unspeakable historical pains. Under the impact of modern civilization, they foster a strong sense of returning to the cultural matriarch, however, they are caught in the embarrassing situation of being self-styled because of their over-conservative attitude towards the other cultures. In short, the Indian image in Aku's poems is multi-dimensional. In the history of American literature, many American authors got used to simplifying the Native Americans into face-painted, feather-decorating barbarians or were simply bound up in creating a tension between their barbaric appearance and noble soul. However, Aku explored a way of shaping the Native American image in ethnographic poetry by looking for a balance in realism and imagination, investigating both the tangible Native American civilization sites and artifacts, as well as intangible cultural heritage such as myths, legends and customs, and visiting Native Americans in all walks of life, including chiefs, dancers, poets, cultural relics collectors and ordinary Indians in the reserve. Through a multi-faceted gaze in the large span of space, Aku succeeds in bring a complex Native American image with rich connotations to the readers.

\section{Horizontal Perspective Ensures the Authenticity of the Native American Image}

D.H. Pageaux believes that all images are derived from the self-consciousness of the relationship between the self and "the other", the native and "the exotic", even this awareness is very weak. Therefore, image is a literary or non-literary expression of the gap between the two types of cultural reality which can explain the relationship between the signifier and signified. (Meng Hua 2001, 155) Therefore, the image must exist in the self-observation and imagination of the other. However, the observer, as the subject or the self, always has three choices when viewing or imagining the object or the other: upward perspective, vertical perspective and horizontal perspective. Different perspectives produce different mindsets and outcomes.

\subsection{Distorted Image of "the Other" Gained by Upward or Vertical Perspective}

In the history of world literature, there are many works that pay attention to the image of foreign countries, but they sometimes look at the other culture from the upward perspective and fictionalize an exotic utopia which essentially demonstrates the author's dissatisfaction and criticism of the local reality. For example, Johann Wolfgang von Goethe viewed the East from an upward perspective. Ancient China is like a paradise in his conversation with Eckermann. "(In China) Everything is clearer, purer and more ethical than here. Everything is understandable, approachable, without strong passions and turbulent poetry... They also have a characteristic that people and nature coexist harmoniously." (Eckermann 2013,112) Yang Wu'neng, a famous Chinese researcher in Goethe study, pointed out: "This picture seems to be very beautiful and clear, but it does not reflect the reality of China; this picture only exists in Confucius and Mencius' moralizing or love stories about talented scholars and beautiful ladies written by those disciples who admired Confucius and Mencius' ethical code. If Goethe has the opportunity to read The Plum in the Golden Vase, Dream of Red Mansions or Peony Pavilion, he will never say anything like that......"(Yang Wu'neng 1991:45-46) Although the lack of understanding about China is one of the reasons for Goethe's idealization of China, the more important reason is that Germany was torn apart and the people were unhappy then, so Goethe did self-criticism through his utopian imagination of China. But contrary to Goethe's view of the other's culture from the upward perspective, some other writers are accustomed to being self-centered and looking at other cultures from a vertical perspective. Their essence is to show their entrenched blind arrogance and superiority. For example, the sinister, dirty, barbaric, ignorant and backward Chinese image portrayed by British writer Christopher New in Shanghai simply aims 
at "constructing the sinister environment for the colonial hero, and contriving an excuse for colonial behavior that the previously backward and poor Shanghai needed the white people to develop, rescue, civilize and modernize".(Chen Xiaolan 2014:162) It is not difficult to see that Christopher New achieves the goal of consolidating his local ideology by smashing and distorting the image of the other. However, the true Chinese image presented by Pearl S. Buck in her masterpiece The Good Earth has fundamentally corrected the unreal image of China in the minds of Westerners. Therefore, Professor Wang Shouren believes that she "objectively describes the life picture of the Chinese people, and expresses the sympathy and humility of the ordinary people on this land."(Wang Shouren 2017)Yao Junwei holds that "the biggest contribution of Pearl S. Buck is that she treats different cultures equally and observes different civilizations from a horizontal perspective. She is a world-class celebrity who bridges communication between the East and West."(Yao Junwei 2014) It is proved by the above three examples that it is impossible to obtain a true image of the object or the other if the observer adopts the upward or vertical perspective in the process of shaping, interpreting and spreading the alien image through intercultural writing, only a horizontal perspective can guarantee the objectivity and authenticity of the image of the other.

\subsection{Authentic Image of the Native American Gained by Horizontal Perspective}

Although the Native American image migrated by Aku is based on poetry, it is a kind of "ethnographic poetry". In other words, the poems recorded by the poet are not fabricated groundlessly, but are based on some sources or facts and created in accordance with the basic aesthetic principles of "real life and real art". In order to obtain this "reality", Aku chose a horizontal perspective in his observation of the Native American civilization. In "Land Upon Sea Turtle", Aku wrote about Nuosu epic The Book of Origins (Hnewo tepyy), He said in the first stanza: "In my ancestors' creation epic/ there is a record of a great flood./ The kind-hearted Jjut mu ssep nyop,/ gained the attention of Heaven with a wisp of smoke,/ proving once again that human reproduction/ is the intent of Nature." Then in the second stanza, he continued the poem with introduction to the Native American myth about world creation. "In the legends of Indians in the North American,/ the unsettled land under their feet/ slowly formed on the back of a turtle/ from the depths of the vast sea, / with the assistance of birds." (Aku 2015:66) It is easy to see that Aku's comparison between the $\mathrm{Yi}$ and the Native American people's views of world creation is not for the purpose of true or false judgment. He only objectively and impartially recorded the different views of the two peoples at the two ends of the earth. So Liang Zhao commented that
Aku's poems are featured with "calm, distanced narrative tone, and contrasting forms". (Liang zhao 2016:130) Thanks to his "calm" and "distance" narration, the Native American image he presented can be more authentic. In "Propitious Crows", he wrote: "there along the Mississippi, / appearing on a bare tree/. Was the first group of/ crows with good omens." In many Indian tribes, crows are regarded as a symbol of cleverness and honor. However, in Yi people's tradition, "For thousands of years,/ Nuosu people in accordance with Hxati tepyy,/ a magic book, / have decoded the language of crows,/ informing the world confidently that/ crows transfer bad news, and/ crows are messengers of disaster." (Aku 2015:75) In the face of such a strong "clash of civilizations", Aku showed neither Goethe-style "fancy" nor Christopher New's "hatred". He only followed the idea of "diversity in harmony", respecting different civilizations, objectively observing the Native American civilization from a horizontal perspective to present a real Native American image in his poems.

Aku's liberal, enlightened and objective attitude towards the Native American civilization can also be found in other poems such as "Medicine Bag", "The Cannibal", "Stealing Fire", "Bones of Beasts" and "Fated with Copper". Regardless of the similarities or differences between the Yi and the Indian in terms of history, culture, mythology, legends, customs, and conception, Aku always tried to suppress his surging emotion with amazing rationality, and used some calm and plain words to demonstrate both the similarities and differences. He said frankly: "My poems, firstly, are a kind of authentic record. However, in regards to the inter-action between subject and object, I do not stand still at the authentic recording of facts. Beyond that, I sublimate the data to authentic thoughts and emotions, and authentic poetic flavor."(Aku 2015:315)

According to Paul Ricœur's point of view in "Du texte à l'action", the imagination of different cultures is divided into "reappearing imagination" and "creative imagination". From Freneau, Longfellow, Cooper, Mark Twain to Hemingway, the Indian images in most American mainstream literature belong to the latter category. They are the Native American images or "illusions" created on the basis of absent object and consciously critical subject. However, Aku, as an investigator from the East, a Yi minority poet and literary anthropologist, did not have the motive for rationalizing the white colonial rule. His special identity made him observe the Native American civilization from a horizontal perspective and thus formed an objective and true image. Even when there was some imagination in his poems which seemed to be above factual life, they were still "reappearing imagination" produced on the basis of field investigation and careful reading of some documents. The biggest difference between the Native American image migrated by $\mathrm{Aku}$ and most American writers lies in its authenticity. Whether it is factual truth, emotional truth, artistic truth or poetic truth, the authenticity he achieved is largely due to his horizontal 
perspective and objective and rational attitude determined by his identity.

\section{Conclusions}

John N. Low, a Native American scholar commented Aku like this: "Whether telling trickster tales or Great Flood stories common to both of our peoples, or relating personal experiences and observations, Aku has an uncanny ability to understand and to lend a fresh voice to our shared experiences. It is both humbling and profound to read the work of an indigenous writer from the other side of the world who relates so well to the indigene of North America." The observer's horizon and perspective largely affect the construction of the image of the observed in a new cultural environment. Although in most cases, cultural filtration is almost inevitable in the process of cultural migration and the original image is bound to be changed or even distorted, the diverse and authentic image brought by Aku's Coyote Traces proves that an image creator's visual field and perspective can largely decide the result of cultural migration. On March 27, 2014, Chinese President Xi Jinping delivered a speech at the UNESCO Headquarter: "Civilization is colorful due to communication, and civilization is enriched by mutual learning. Civilization exchanges and mutual learning are important dynamos to promote the progress of human civilization and the peaceful development of the world."'(Li Feng \& Yuan Bo 2019) The objective and authentic Native American image with rich connotations migrated by $\mathrm{Aku}$ from America to China will play an important role in building a community with a shared future for mankind through the exchange of civilizations.

\section{Notes}

1. Aku Wuwu (ap kup vyt vy; 罗庆春Luo Q ingchun) was born in 1964 in Liangshan Yi Autonomous Prefecture, Sichuan, China in 1964. He is a poet of the Yi ethnic minority who writes in his native tongue (Nuosu language) and Chinese mandarin and endeavors to popularize Yi poetry internationally. Aku Wuwu's tri-lingual poem collection Tiger Traces: Selected Nuosu and Chinese Poetry of Aku Wuwu (2006) is the first volume of Nuosu language poetry to be published in the United States. His bi-lingual poem collection Coyote Traces: Aku Wuwu's Poetic Sojourn in America (2015) was published both in China and the USA. Translations of his poems have appeared in numerous literary journals and anthologies in the United States and Japan, including Blood Ties: Writing across Chinese Borders (ed. by Richard Frank Stewart, 2005), Basalt (ed. by Jodi Varon, 2007), Language for a New Century: Contemporary Poetry from the Middle East, Asia, and Beyond (ed. by Tina Chang, 2008), The
Borderlands of Asia : Culture, Place, Poetry (ed. by Mark Bender, 2017), Chinese Literature Today, Manoa, Cha, and Silk Road.

\section{Acknowledgments}

This article is funded by the Sichuan Yi Culture Study Center's project "Study of Aku Wuwu's Poetic Sojourn in America from the Perspective of Comparative Literature" (YZWH1918) and "Ideological and Political Education in English and American Literature Courses" (BKJX2019073) supported by Chengdu University of Information Technology.

\section{REFERENCES}

[1] Akuwuwu. 2015. Coyote Traces: Aku's Poetic Sojourn in America[M]. Tr. Peihong Wen, Bender Mark. Beijing:The Ethnic Publishing House.

[2] Akuwuwu.2015. Age of Mixed Blood[M]. Beijing: Writers Publishing House.

[3] Chevrel,Yves. 1989. littérature comparée[M]. Paris: Presses Universitaires de France.

[4] Churchill, Ward. 1998. Fantasies of the Master Race: literature $[\mathrm{J}]$. Cinema and the Colonization of American Indians. San Francisco: City Lights Books.

[5] Daju, Lan. 1996. American Native Americans - American Indian Scholars Talking about American Indians[J]. World Ethno-National Studies.no.3:78-80.

[6] Eckermann,Johann Peter. 2013. Gespräche mit Goethe[M]. Tr. Guangqian Zhu, Beijing: Zhong Hua Book Company.

[7] Feng, Li \& Yuan Bo. Mar.26, 2019.Xi Jingping: Civilization is Colorful due to Communication [EB/OL].http://politics.p eople.com.cn/n1/2019/0326/c1001-30996745.html.

[8] Hua, Meng, ed. 2001. Imagologie of Comparative Literature[M]. Beijing: Beijing University Press.

[9] Junwei, Yao. 15 Jan,2014. Pearl S. Buck Told Chinese Stories to the World[N]. Xin Hua Daily.

[10] Ramsay, Gerald. 1983. Indian Myths and Legends in Oregon, USA. trans. Kun Shi \& Wusheng Li, Beijing: Chinese Folk Literature Publishing House.

[11] Seattle. 2019. Chief Seattle Speech [EB/OL] http://www.m essengersofthelight. com/Seattle.htm.

[12] Shouren, Wang. June 30,2017. Pearl S. Buck: Telling Chinese Stories all her Life[N]. Xin Hua Daily.

[13] Wu'neng Yang. 1991. Goethe and China[M]. Beijing: SDX Joint Publishing Company.

[14] Xiaolan Chen. 2014.Gender, City, Alien: A Transcultural Interpretation of Literary Theme[M]. Shanghai: Fu Dan 
University Press.

[15] Xiaoming, Wu. 2012. Differences and Identity in Cultural Communication[J]. Chinese Culture, no.2:.41-54.
[16] Zhao, Liang. 2016. India in an Yi Poet's Eye: Cross-Cultural Writing in Aku's Coyote Traces [J]. Ethnic Arts Quarterly, no. 1:27-133. 